\title{
Professor Anita Hill versus Judge Clarence Thomas: The view of students at a Southern university
}

\author{
RUSSELL EISENMAN \\ McNeese State University, Lake Charles, Louisiana
}

\begin{abstract}
In the televised United States Senate Judiciary Committee hearing on Judge Clarence Thomas as a nominee to the U.S. Supreme Court, law professor Anita Hill claimed that she had suffered sexual harassment from Judge Thomas 10 years earlier. Right after the hearing, students in two undergraduate classes at a Southern university were asked who they believed the most, Professor Hill or Judge Thomas. Although about 25\% of the population of the United States reported believing Professor Hill, her support in these two classes was almost nonexistent. Only one student in each class believed Professor Hill. The results are consistent with the expectation that Southern university students, both male and female, would be less likely than the national average to believe her sexual harassment charges. However, the strength of the findings was surprising.
\end{abstract}

People's beliefs may be based on a variety of things, including how they reason about a particular issue, their background in terms of how they have been raised, socioeconomic status, what information they have been previously exposed to, what information they remember, cognitive ability, what they are reinforced for, and so forth. What is true for one group may not be true for another, and exposure to information may not necessarily change opinion. Eisenman (1993) found that students who liked David Duke, a former Ku Klux Klan leader and pro-Nazi, typically retained their positive views of Duke even after watching the Public Broadcasting film "Who is David Duke?"' This film revealed him to be currently racist, antiSemitic, and pro-Nazi, all things he has denied in his political campaigns. Yet, students who, before the film, said they liked him or saw him as nonracist, typically held these same views after seeing the film. The percentage of white students who indicated liking Duke was just over 50\%, which was the same as in an earlier study (Eisenman, 1992) and the same as the white vote in Duke's campaign for U.S. Senator from Louisiana in 1990 (Eisenman, 1992; Freemantle, 1990). People may resist information that would upset other parts of their belief system (Festinger, 1957; Heider, 1946).

In 1991, the U.S. Senate Judiciary Committee held televised hearings on the nomination by Republican President George Bush of Judge Clarence Thomas to join the U.S. Supreme Court. The nomination was controversial, since Judge Thomas, although black, was seen as a con-

I thank numerous people for discussions related to this study: Carl A Bartling, Linda Brannon, Bob Eisenman, Henry B. Sirgo, Jerry Whiteman, David Eisenman, Georgia Eisenman, and Susan Eisenman. The usual caveats about responsibility apply. Address reprint requests to Russell Eisenman, Department of Psychology, McNeese State University, Lake Charles, LA 70609-1895. servative opposed to abortion, affirmative action, and government help for blacks. A former employee, law professor Anita Hill, who is also black, testified that 10 years earlier, when Judge Thomas was her supervisor, he had subjected her to sexual harassment by making repeated, unwanted requests for dates and using vulgar sexual language. Judge Thomas denied the charges. Thus, the nation saw, via television, a battle in which Judge Thomas's character was called into question. Professor Hill's credibility was also questioned, since she had waited so long to air the charges. The concept of sexual harassment is a controversial one, which has recently received increased interest from government, employers, and researchers (Bartling \& Eisenman, 1993).

Polls showed that, at the end of the hearings, about 25\% of the population of the United States believed Professor Hill. A Newsweek poll broke down the issue by gender and found that women were more likely than men to believe Professor Hill, while men were more likely to disbelieve her. Specifically, the percentages of respondents among women and men who believed that Judge Thomas sexually harassed Professor Hill were $27 \%$ and $17 \%$, respectively. Those who disbelieved her charges were $37 \%$ of the women and $41 \%$ of the men ("Newsweek poll," 1991). Other articles showed the intensity of the issue and that women tended to see the Hill-Thomas debate as more relevant than did men (Alter, 1991; "A moment," 1991; Kaplan, 1991; Shapiro, 1991).

The concern of the present study was whether or not students at a Southern university would see the debate the same way as the general population did. There is reason to think that, to some extent, they would not. The role of Southern women has traditionally been to be a housewife who does not work and certainly does not bring charges against her employer (Dillman, 1988). This has, to an extent, been the role for women in general in the United States, but re- 
cent years have seen great change (Roman, ChristianSmith, \& Ellsworth, 1988). If the South is more traditional than the rest of the nation with regard to the role of women, then students queried at a Southern university might be less likely than the national average to believe Professor Hill's sexual harassment charges. Also, since the national data showed that more women than men believed Professor Hill, it is possible that this sex difference would again manifest itself with the college students, although the overall support for Professor Hill might be low.

\section{METHOD}

\section{Subjects}

The participants were from two introduction to psychology classes taught by the author. One class had 58 students; the other had 28 students. The first class was composed of 29 men and 29 women; the second class had 11 men and 17 women.

\section{Procedure}

The week after the hearings concluded, at the start of class, the teacher asked for a show of hands regarding who the students believed more, Professor Hill or Judge Thomas. To control for effects of the order in which things were asked, Class 1 was asked, "Who do you believe the most, Professor Anita Hill or Judge Clarence Thomas?' while Class 2, was asked, "Who do you believe the most, Judge Clarence Thomas or Professor Anita Hill?"' Also, in Class 1, women were asked to raise their hands first in their vote and then men were asked to do so; this was reversed in Class 2 . No order effects were obtained.

\section{RESULTS}

All statistical findings reported represent two-tailed binomial tests. Only 1 student in each class believed Professor Hill. Both were black women, but there were also black women who believed Judge Thomas more. For Class 1, among women, 1 believed Professor Hill more and 28 believed Judge Thomas more $(p<.001)$; among men, 0 believed Professor Hill and 29 believed Judge Thomas $(p<.001)$. Class 2 replicated these findings: among women, 1 believed Professor Hill and 16 believed Judge Thomas $(p<.002)$; among men, 0 believed Professor Hill and 11 believed Judge Thomas $(p<.002)$.

\section{DISCUSSION}

The results support the expectation that Southern university students would be less likely than the national norm to believe Professor Hill's sexual harassment charges against Judge Thomas. There was no gender difference, since only 2 students believed Professor Hill. Many of the women students were vociferous in their condemnation of Professor Hill as a liar. Most of these students worked and could possibly find them- selves facing workplace harassment, but this did not make them empathic toward her. Clearly, she was not believed by this sample. Further strengthening the findings is the fact that discussions with two other psychology professors, at the same university, yielded information that in their classes only 1 student spoke in favor of Professor Hill, which is exactly what was found with the present data.

The concept of sexual harassment may be too new for these students to have much persuasive power (Bartling \& Eisenman, in press). Also, the traditional female role in the United States in general, but especially in the South, might preclude a woman from making trouble for her boss (Dillman, 1988). Thus, from this perspective, Professor Hill did not know her place, much as blacks who asserted their rights in previous times were considered to be troublemakers who did not know their place. The fact that Professor Hill waited 10 years to mention her alleged harassment also was a factor decreasing her credibility, as several students mentioned in discussion.

The findings show that we cannot always generalize from national polls. Polls in general may have problems with accuracy, as shown by the failure of pollsters and political experts to predict accurately the strength of former Ku Klux Klan leader David Duke when he ran for the U.S. Senate (Eisenman, 1992). Regional differences may mean that what is true in one area may not hold up in other areas. The sampling may limit the findings, which applies to national or regional surveys, as well as to research carried out at any given institution. Attitudes in one region may not predict attitudes in another region.

\section{REFERENCES}

Alter, J. (1991, October 21). Why there isn't a better way. Newsweek, p. 45 .

A moment of truth. (1991, October 21). Newsweek, p. 24

Bartling, C. A., \& Eisenman, R. (1993). Sexual harassment proclivities in men and women. Bulletin of the Psychonomic Society, 31, 189-192.

Dillman, C. M. (ED.) (1988). Southern women. New York: Hemisphere.

EISENMAN, R. (1992). Creativity, social and political attitudes, and liking or disliking David Duke. Bulletin of the Psychonomic Society, 30, 19-22.

Eisenman, R. (1993). Student attitudes toward David Duke before and after seeing the film "Who is David Duke?" Bulletin of the Psychonomic Society, 31, 37-38.

FEsTINGER, L. (1957). A theory of cognitive dissonance. Stanford, CA: Stanford University Press.

Freemantle, T. (1990, October 8). Strong finish indicates Duke is future force. Houston Chronicle, pp. 1A, 6A.

HeIDER, F. (1946). Attitudes and cognitive organization. Journal of Personality, 21, 107-112.

Kaplan, D. A. (1991, October 21). Anatomy of a debate. Newsweek, pp. 26-32.

NEWSWEEK POLL. (1991, October 21). Newsweek, p. 28.

Roman, L. G., Christian-Smith, L. K., \& Ellsworth, E. (Eds.) (1988). Becoming feminine: The politics of popular culture. New York: Falmer.

ShapiRo, L. (1991, October 21). Why women are angry. Newsweek, pp. 41-44.

(Manuscript received August 24, 1992.) 